

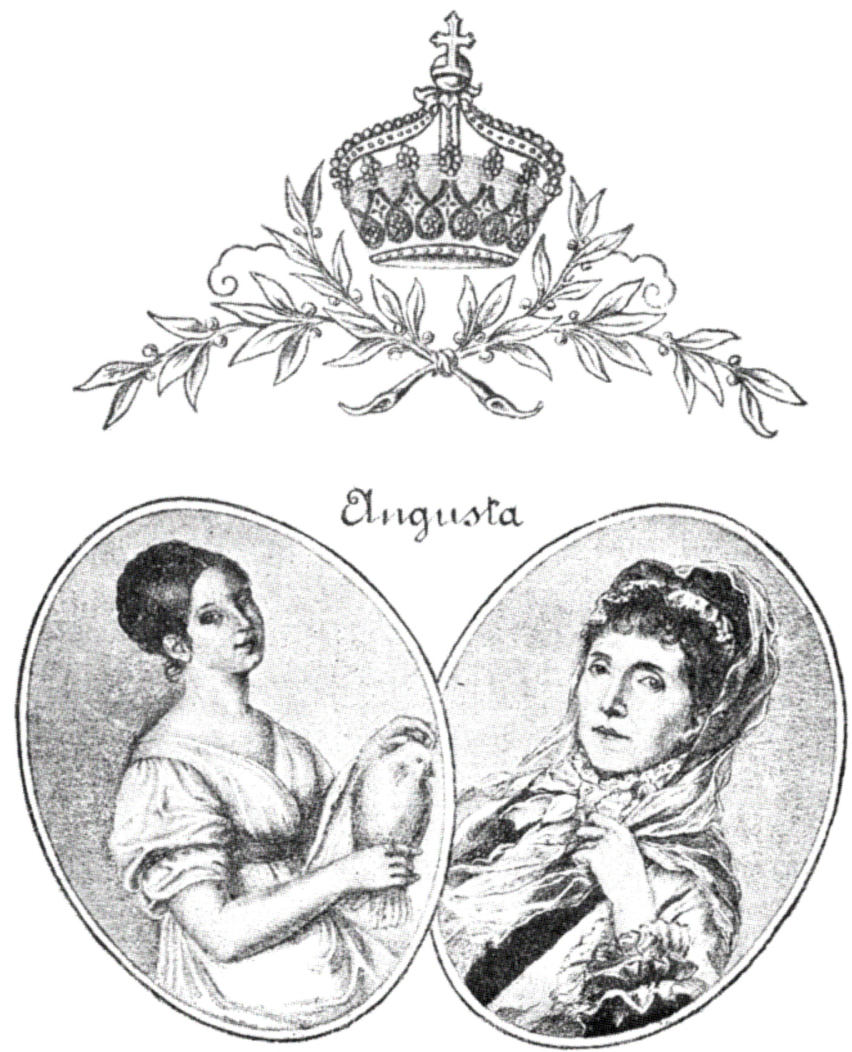

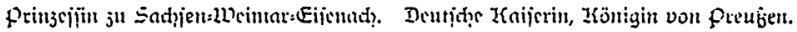

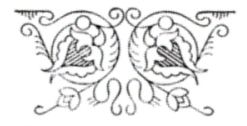




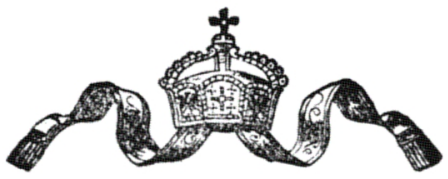

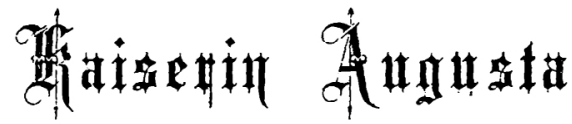

von

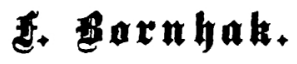

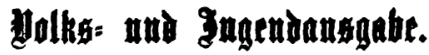

\author{
.Deffet rerben auf ber Belt fant \\ es nut burd bie Buten." \\ Ronigin Buife.
}

\section{Butite Auflage.}

아마 므응

Berlin 1889.

3. I. Fieines Derlag. 

Jhril

Königlidan bobeit

der Durđllauđhtigften

\section{$\mathfrak{f r a u}$ Groḱkherjogin}

\section{suife von $B$ aden}

geb. Prinzeffim von Preufen

in tiefiter Ehrfurḑt gewiomet

volt

der Derfafferin. 
